\title{
Pengaruh Kesadaran Lingkungan dan Corporate Social Responsbility dengan Komite Audit Independen sebagai Pemoderasi Dalam Meningkatkan Kualitas Laba BUMN di Indonesia
}

\author{
Ronny Bagus Witjaksono ${ }^{1}$, Darmansyah ${ }^{2}$
}

${ }^{1,2}$ Universitas Pancasila, Jl. Raya Lenteng Agung, Jagajarsa, Jakarta Selatan, 12640

\section{N F O ARTIKEL ABSTRACT}

\section{JEL Classification:}

M14

M41

\section{Keywords:}

environmental awareness,

corporate social

responsibility,

audit committee,

earning quality
The purpose of this study was to analyze the influence of environmental awareness and Corporate social responsibility by the audit committee as moderating in improving the quality of SOE profits. The analytical method used is the test 4.0 WarpPLS program. The results showed that there was no significant influence of environmental consciousness affects the quality of SOE profits. There is a significant relationship between Corporate social responsibility affect the quality of SOE profits. No Effect of the Audit Committee the Independent and weaken the influence of Corporate social responsibility on the Quality of Earnings. Independent Commissioners significantly moderate the effect of CSR on the quality of earnings. However, the audit committee is not able to significantly moderate the influence of CSR on the quality of earnings.

\begin{abstract}
A B S T R A K
Tujuan penelitian ini adalah untuk menganalisis pengaruh kesadaran lingkungan dan Corporate Social Responsbility dengan komite audit sebagai pemoderasi dalam meningkatkan kualitas laba BUMN. Metode analisis yang digunakan adalah uji menggunakan program WarpPLS 4.0. Hasil penelitian tersebut menunjukkan bahwa tidak ada pengaruh yang signifikan antara kesadaran lingkungan berpengaruh terhadap kualitas laba BUMN. Ada pengaruh yang signifikan antara Corporate social responsibility berpengaruh terhadap kualitas laba BUMN. Tidak ada Pengaruh Komite Audit Independen dan memperlemah pengaruh Corporate social responsibility terhadap Kualitas Laba. Komisaris independen secara signifikan memoderasi pengaruh CSR terhadap kualitas laba. Namun demikian Komite audit tidak mampu secara signifikan memoderasi pengaruh CSR terhadap kualitas laba.
\end{abstract}

\section{Pendahuluan}

Kualitas laba mulai dari laba bersih (net earnings). Laba bersih dasar dalam melakukan penilaian terhadap kualitas laba. Analisis kualitas laba yang berbeda akan menyebabkan pertimbangan-pertimbangan yang berbeda mengenai karakteristik suatu laba. Menurut Seigel dalam menyusun karakteritik dalam menilai kualitas laba dengan sesuai dengan resiko yang dimiliki perusahaan.Untuk mengukur kualitas laba dapat dilakukan melalui kriteria Earnings Quality Assessment (EQA). Kriteria EQA menyediakan ukuran independen untuk melakukan assessmen terhadap kualitas laba perusahaan, sehingga dapat diketahui kualitas

*Email Korespondensi: ${ }^{1}$ mahesa_triartha@yahoo.com, 2darmansyahs155@yahoo.com 
laba dan mengevaluasi beberapa periode laporan keuangan. Selain itu untuk model EQA dapat juga digunakan untuk menilai stabilitas laba yang dapat membawa pada pemahaman yang lengkap terhadap potensi laba masa datang. Laba di masa depan menjadi indikator kemampuan membayar deviden masa mendatang. Untuk mengukur kualitas laba menggunakan indicator antara lain kualitas laba didasarkan pada perbedaan relatif persistensi akrual terhadap arus kas, estimasi kesalahan dalam proses akrual, ketiadaan manajemen laba, dan konservatisme.

Komisaris independen memiliki pengaruh signifikan terhadap nilai perusahaan dengan arah positif. Dapat disimpulkan bahwa keberadaan komisaris independen dalam perusahaan dapat memantau dan meningkatkan perusahaan dalam melaksanakan good corporate governance. Sedangkan menurut Fauziah et.al (2014) komite audit tidak mampu secara signifikan memoderasi pengaruh CSR terhadap kualitas laba.

Peran CSR telah memberikan pengaruh terhadap perusahaan. Berdasarkan hasil penelitian Susanto et al menunjukkan bahwa pengungkapan Corporate social responsibility tidak memiliki pengaruh signifikan terhadap nilai perusahaan. Hal ini dapat dikarenakan perusahaan belum mengkomunikasikan Corporate social responsibility secara tepat dan sebagian besar perusahaan publik hanya berfokus pada faktor keuangan. Hasil ini juga menunjukkan bahwa pengungkapan Social Responsibility bukan faktor penting yang dipertimbangkan investor dalam berinvestasi dalam suatu perusahaan. Berdasarkan hasil penelitian Fauziah et.al (2014) pengaruh CSR terhadap kualitas laba perusahaan Indeks CSR berpengaruh positif signifikan terhadap kualitas laba. Semakin tinggi indeks CSR maka semakin tinggi pula kualitas laba perusahaan dan sebaliknya.

Faktor keuangan merupakan faktor utama yang mempengaruhi nilai perusahaan (Mulianti, 2010). Namun, bagi investor faktor non keuangan juga sangat berpengaruh terhadap kinerja perusahaan yang berdampak terhadap nilai perusahaan. Bagi Investor corporate social responsibility (CSR) merupakan salah satu faktor non keuangan yang sekarang ini perlu dipertimbangkan oleh perusahaan dalam upaya meningkatkan nilai perusahaan. CSR yang dilakukan secara konsisten dalam jangka panjang akan meningkatkan legitimasi masyarakat terhadap kehadiran perusahaan. Semakin banyak bentuk pertanggungjawaban yang dilakukan perusahaan terhadap lingkungannya, image perusahaan menjadi meningkat.

Kualitas laba merupakan sesuatu yang sentral dan penting dalam dunia akuntansi karena berdasar kualitas laba tersebut profesi akuntansi dipertaruhkan. Investor, kreditor dan para pemangku kepentingan lainnya mengambil keputusan salah satunya berdasar pada laporan keuangan, apabila kualitas laba yang disajikan tidak dapat di andalkan maka para pemangku kepentingan tidak dapat percaya lagi pada profesi akuntansi. Oleh karena itu berbagai upaya dan studi terus dilakukan agar dapat menyusun laporan keuangan dengan kualitas laba yang tinggi. Para akuntan publik mengaudit dengan baik, untuk meyakinkan bahwa laporan keuangan disusun secara wajar sehingga laba yang disajikan berkualitas.

Tujuan penelitian ini adalah untuk menganalisi pengaruh kesadaran lingkungan dan corporate social responsbility dengan komite audit sebagai pemoderasi dalam meningkatkan kualitas laba BUMN. Lebih rinci tujuan penelitian adalah menganalisis kesadaran lingkungan berpengaruh terhadap kualitas laba BUMN, menganalisis Corporate social responsibility berpengaruh terhadap kualitas laba BUMN dan menganalisis Corporate social responsibility berpengaruh terhadap Kualitas Laba ketika dimoderasi oleh Komite Audit Independen.

\section{Telaah Teori dan Pengembangan Hipotesis}

\section{Akuntansi Lingkungan}

Menurut Umami (2010) pengertian akuntansi lingkungan dijabarkan sebagai berikut akuntansi lingkungan merupakan bagian dari bidang akuntansi yang menyediakan laporan baik untuk pengguna internal maupun eksternal. Untuk pihak internal, akuntansi lingkungan dapat 
membantu membuat keputusan manajemen dalam hal harga, pengendalian overhead, dan penganggaran modal. Sedangkan untuk pengguna eksternal untuk pengungkapan informasi lingkungan kepada masyarakat dan komunitas keuangan.

Peran akuntansi lingkungan menurut Pratiwi (2013) adalah memberikan tambahan informasi melalui pengungkapan (disclosure) wajar atau dalam data kuantitatif pada komponen laporan keuangan yang diterbitkan secara berkala serta menunjukkan kegiatan dan hasil operasional perusahaan yang mencakup dimensi ekonomi, sosial, dan lingkungan. Dari definisi di atas dapat disimpulkan bahwa akuntansi lingkungan merupakan alat komunikasi organisasi baik kepada pengguna internal maupun eksternal dari kegiatan konservasi yang dilakukan oleh perusahaan

\section{Kualitas Laba}

Kualitas laba dapat didefinisikan sebagai kemampuan laba dalam menjelaskan informasi yang terkandung di dalamnya yang dapat membantu pembuatan keputusan oleh pembuat keputusan (Dechow et al., 2010). Laba merupakan produk akuntansi akrual dan digunakan sebagai alat ukur terhadap Kualitas Laba manajemen perusahaan (Bissessur, 2008). Semakin baik laba dalam menerangkan Kualitas Laba manajemen maka semakin berkualitas laba tersebut.

Kualitas laba memiliki banyak dimensi dan dapat diukur dengan banyak ukuran, salah satunya menggunakan akrual. Akrual adalah perbedaan antara laba bersih dengan arus kas dari aktivitas operasi (Sloan, 1996 dalam Richardson et al, 2001). Kegunaan utama akrual adalah mengurangi masalah waktu dan ketidakpadanan dari arus kas (Dechow, 2001 dalam Schoemaker, 2013).

Dechow dan Schrand (2004) dalam Sirait (2012) mendefinisikan laba yang berkualitas setidaknya mengandung karakteristik dasar, yakni merefleksikan Kualitas Laba operasi perusahaan saat ini dan menjadi indikator yang baik atas persistensi Kualitas Laba operasi perusahaan dimasa yang akan datang. Givoly et al. (2010) mendefinisikan kualitas laba sebagai kemampuan laba dalam merefleksikan kebenaran laba perusahaan dan membantu memprediksi laba dimasa mendatang, dimana terdapat 4 ukuran untuk memproksikan kualitas laba, yaitu accrual persistence, estimation error in the accruals process, absence of earnings management, dan conservatism.

Menurut Schipper dan Vincent (2003) dalam Sutopo (2001), Kualitas laba menunjukkan tingkat kedekatan laba yang dilaporkan dengan hicksian income, yang merupakan laba ekonomik yaitu jumlah yang dapat dikonsumsi dalam satu periode dengan menjaga kemampuan perusahaan pada awal dan akhir periode tetap sama.

Schipper dan Vincent (2003) dalam Sutopo (2001) mengelompokkan konstruk kualitas laba dan pengukurannya berdasarkan cara menentukan kualitas laba, yaitu berdasarkan: sifat runtun-waktu dari laba, karakteristik kualitatif dalam rerangka konseptual, hubungan laba-kasakrual, dan keputusan implementasi.

\section{Kesadaran Lingkungan}

Seiring dengan meningkatnya kesadaran masyarakat pentingnya menjaga lingkungan dan memelihara lingkungan seperti dampak yang akan dirasakan manusia karena global warming atau pemanasan global, yang disebabkan oleh kerusakan lingkungan maka kebutuhan masyarakat akan informasi mengenai bentuk tanggung jawab perusahaan akan Kualitas Laba lingkungan semakin meningkat.

Kotler (2005) dalam Lenny (2006) memaparkan manfaat melakukan tanggung jawab lingkungan dan sosial perusahaan dalam strategi dan operasi bisnis, yaitu: meningkatkan penjualan dan saham di pasaran, menguatkan posisi merk, meningkatkan citra dan pengaruh perusahaan, meningkatkan kemampuan untuk menarik, mempertahankan karyawan dan mengurangi biaya operasi, meningkatkan kemampuan untuk menarik investor dan analis keuangan.

\section{Corporate social responsibility (CSR).}

Menurut Carrol (1979) menunjukkan komponen CSR ke dalam empat kategori, yaitu : 1. Economic responsibilities yang merupakan 
tanggung jawab sosial utama perusahaan. Perusahaan harus dapat mengelola tanggung jawab ekonominya kepada stakeholder

2. Ethical responsibilities yang menunjukkan bahwa stakeholder berharap perusahaan menjalankan bisnis secara etis

3. Legal responsibilities yang menunjukkan bahwa stakeholder berharap perusahaan yang menjalankan usahanya mampu memenuhi tanggungjawab hukum dengan mematuhi peraturan perundang-undangan yang berlaku.

4. Discretionary responsibilities yang menunjukkan bahwa stakeholder mengharapkan keberadaan perusahaan dapat memberikan manfaat bagi mereka. Dengan demikian perusahaan yang melakukan CSR harus melaksanakan keempat komponen tersebut.

\section{Komite Audit}

Komite Audit mempunyai wewenang untuk menjalankan tugas-tugasnya seperti yang diutarakan oleh Barol (2004) yang dikutip oleh Siswanto dan Aldridge (2005, 237), yaitu: "Mengaudit kegiatan manajemen perusahaan dan auditor (intern dan ekstern). Mereka yang berwenang meminta informasi tambahan dan memperoleh penjelasan dari manajemen dan karyawan yang bersangkutan. Komite Audit juga mengevaluasi seberapa jauh peraturan telah mematuhi standar akunting dan prinsip akuntansi yang diterima di Australia."
Sedangkan menurut Hasnati (2003) yang dikutip oleh Indra dan Ivan (2006, 149), Komite audit memiliki wewenang, yaitu:

1. Menyelidiki semua aktivitas dalam batas ruang lingkup tugasnya;

2. Menyelidiki semua aktivitas dalam batas ruang lingkup tugasnya;

3. Mencari Informasi yang relevan dari setiap karyawan;

4. Mengusahakan saran hukum dan profesional lainnya yang independen apabila dipandang perlu.

\section{Kesadaran Lingkungan dan Kualitas Laba}

Isu lingkungan sekarang sudah merupakan isu penting dan ditandai dengan maraknya pembicaraan dalam agenda politik, ekonomi dan sosial,khususnyamasalahpencemaranlingkungan dan penurunan kualitas hidup. Kesadaran akan luasnya dampakkebidangyang lainnya.Kesadaran masyarakat akan pentingnya lingkungan dapat dilihat dari dibentuknya lembaga-lembaga atau gerakan peduli lingkungan. Sedangkan usaha dari pemerintah adalah ditetapkannya berbagai undang-undang dan peraturan yang mengatur kelestarian alam, pencegahan efek limbah beracun dari operasi industri, pelarangan perusahan elemen lingkungan. Salah satu wujud dari respon dari dunia adalah dengan melakukan kegiatan CSR. Dalam penelitian Sun et.al (2010) bahwa hubungan antara pengungkapan lingkungan perusahaan dengan kualitas laba berpengaruh

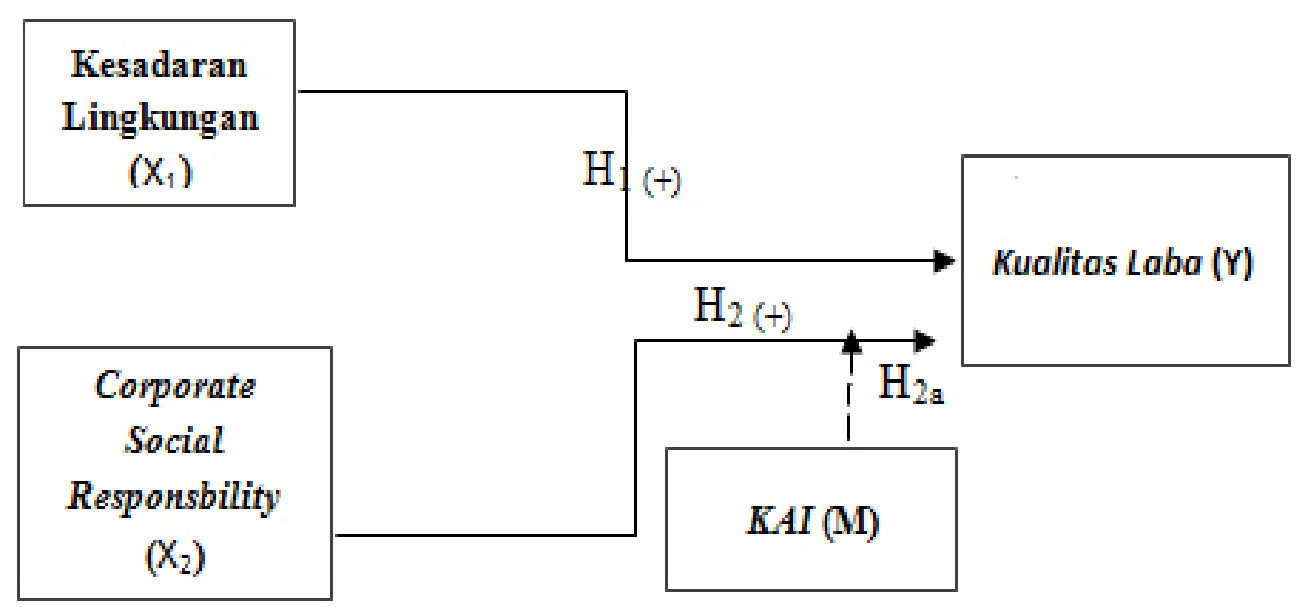

Gambar 1. Kerangka Pikir 
signifikan dan positif, namun dari hasil penelitian tersebut perlu ditambahkan variabel corporate governance untuk meningkatkan kedua variabel tersebut.

Pemerintah dan masyarakat semakin menyadari semakin pentingnya lingkungan. Usaha pemerintah adalah ditetapkannya berbagai undang-undang dan peraturan yang mengatur kelestarian alam, pencegahan dampak dari operasi industri,. Perusahaan telah melakukan respon secara proaktif terhadap gerakan kesadaran dan peraturan mengenai lingkungan agar dapat bertahan dalam jangka panjang.

H1 : Terdapat pengaruh positif antara kesadaran lingkungan terhadap kualitas laba

\section{Corporate Social Responsbility dan Kualitas Laba}

CSR adalah satu bentuk tanggungjawab sosial atas usaha yang meliputi ekonomi, legal, etika, dan discretionary yang diharapkan masyarakat atas suatu organisasi pada saat itu. SCR merupakan salah satu upaya yang dilakukan oleh manajemen untuk meningkatkan reputasi perusahaan dan memberikan pandangan (image) yang positif terhadap perusahaan stakeholder yaitu dengan implementasi CSR. CSR dapat menurunkan kemungkinan adanya tekanan dari stakeholders yang tidak puas atau yang kepercayaannya menurun karena manajemen laba. Efek jangka panjang implementasi CSR, perusahaan dapat memiliki hubungan yang baik dengan stakeholders. Dalam penelitian yang dilakukan Fauziah dkk (2014) dan Isyanto dkk (2014) terhadap pengaruh Corporate social responsibility terhadap kualitas laba perusahan menunjukkan adanya hubungan positif antara kegiatan CSR dan kualitas laba. Kegiatan CSR memberikan pengaruh positif terhadap kualitas laba.

Perkembangan kesadaran masyarakat tentang tanggung social manajemen terhadap stakeholder. Sehingga masyarakat memiliki ekspektasi yang besar terhadap perusahaan untuk dapat memberikan informasi yang transparan terkait bisnis yang dilakukan perusahaan. Pengungkapan CSR yang dilakukan oleh manajemen memiliki dampak yang positif dan negatif. Dampak negatif dari pengungkapan CSR adalah manajemen dapat menggunakan pengungkapan CSR untuk menutupi perilaku manajemen laba yang dapat menurunkan kualitas laba. Di lain pihak, dengan pengungkapan CSR maka manajemen dapat menjalin hubungan jangka panjang dengan stakeholders untuk memberikan image yang positif terkait dengan kondisi perusahaan.

H2 : Terdapat pengaruh positif antara Corporate Social Responsbility terhadap kualitas laba

H2a : Terdapat pengaruh positif antara Corporate Social Responsbility terhadap kualitas laba ketika di moderasi oleh Komite Audit

\section{Metode}

Dalam penelitian ini digunakan metode survey untuk memperoleh data penelitian dari responden yang dipilih sebagai sampel penelitian. Dalam metode survey, peneliti akan menggunakan instrument penelitian berupa daftar pertanyaan atau kusioner yang akan diberikan kepada responden. Kuesioner dimaksud berisi pernyataan dengan pilihan jawaban yang diharapkan mampu menangkap hal atau kondisi di lapangan yang dirasakan oleh para responden. Jenis data yang diperoleh dari metode survey adalah data kualitatif yang dikuantitatifkan dengan menggunakan skala likert. Dalam skala likert, jawaban responden akan dikelompokkan dalam pernyataan-pernyataan jawaban pilihan yang masing-masing akan diberikan skor tertentu. Skoring yang diberikan dalam skala likert menunjukkan tingkat atas persepsi yang diberikan oleh para responden.

Populasi penelitian ini adalah seluruh data terkait dengan laba BUMN. Sedangkan tahun sampel yang digunakan adalah periode tahun 2013-2015, dengan asumsi bahwa data yang tersedia lengkap serta memungkinkan untuk menjadi penelitian adalah ditahun tersebut. Jumlah Populasi BUMN di Indonesia adalah sebanyak 135 BUMN. Sedangkan populasi 
sasaran BUMN kontruksi dan kawasan industri ada sebanyak 96 BUMN.

Sampel penelitian ini ditentukan dengan menggunakan teknik purposive sampling. Purposive sampling adalah pengambilan sampel secara sengaja sesuai dengan persyaratan sampel yang diperlukan seperti sifat, karakteristik, ciri dan kriteria sampel. ditetapkan kriteria inklusi yaitu:

a. Perusahaan BUMN yang bergerang kontruksi sektoral Property

b. Perusahaan BUMN yang terdaftar sebagai Kompas 100 dan Pefindo25

c. Data kualitas laba Perusahaan periode 20132015

Tabel 1. Populasi dan Sampel

\begin{tabular}{llll}
\hline JENIS BUMN & Populasi & $\%$ & Sampel \\
\hline Populasi I & & & \\
Perbankan & 5 & $12.8 \%$ & \\
Asuransi & 14 & $35.9 \%$ & \\
Perjam Rumah Sakit dan Jasa Lainnya & 20 & $51.3 \%$ & \\
Jumlah & 39 & $100.0 \%$ & \\
Populasi 2 (Populasi Sasaran) & & & \\
Jasa Konstruksi & 16 & $16.7 \%$ & 8 \\
Kawasan Industri & 80 & $83.3 \%$ & 41 \\
Jumlah & 96 & $100.0 \%$ & 49 \\
\hline
\end{tabular}

Data Per April 2016

Berdasarkan hasil ketentuan perhitungan rumus sampel di atas, maka diketahui jumlah sampel adalah 49 BUMN kontruksi dan kawasan industri yang menerapkan CSR. Pengambilan sampel dilakukan dengan cara Purposive sampling berdasarkan penilaian (judgment) peneliti mengenai siapa-siapa saja yang pantas (memenuhi persyaratan) untuk dijadikan sampel. Sebanyak 49 BUMN dibidang kontruksi

Variabel, Definisi dan Pengukura
Sehingga jumlah sampel dalam penelitian ini ditetapkan sebanyak 25 BUMN bidang kontruksi sektoral Properti dan terdaftar Kompas100/ Pefindo25 sesuai kriteria yang ditetapkan.

Teori ini dipergunakan sebagai landasan atau alasan mengapa suatu variable bisa mempengaruhi variabel dependen, berikut ini :

\section{$\begin{array}{lll}\text { Variabel } & \text { Definisi operasional } & \text { Alat Ukur }\end{array}$}

K e s a d a r a n Lingkungan
Selisih antara pendapatan yang direalisasi dari transaksi perusahaan yang terjadi

Kualitas Laba selama satu periode, dengan biaya yang berkaitan dengan pendapatan tersebut (Chariri, 2005).

Kualitas Laba perusahaan dalam menciptakan lingkungan yang baik (Lenny, 2006)
Data Situs resmi BUMN

CAR $=$ Income $-\mathrm{R}$ alisasi $\operatorname{Tr} x$

$$
E=\frac{\text { Anggaran CSR }}{\sum \text { Total Anggaran }}
$$




\begin{tabular}{|c|c|c|}
\hline $\begin{array}{l}\text { Corporate Social } \\
\text { Responbility }\end{array}$ & $\begin{array}{l}\text { Tindakan yang dilakukan oleh perusahaan } \\
\text { sebagai rasa tanggung jawab perusahaan } \\
\text { terhadap social maupun lingkungan sekitar } \\
\text { dimana perusahaan itu berada (Carrol, } \\
\text { 1979) }\end{array}$ & $\begin{array}{l}\text { Data Situs resmi BUMN } \\
C S R=\% \text { Nett } \mathbf{P} \text { ofit }\end{array}$ \\
\hline $\begin{array}{l}\text { V a r i a b e l } \\
\text { Moderasi } \\
\text { Komite Audit }\end{array}$ & $\begin{array}{l}\text { Sekelompok orang yang dipilih oleh } \\
\text { kelompok yang lebih besar untuk } \\
\text { mengerjakan pekerjaan tertentu atau untuk } \\
\text { melakukan tugas-tugas khusus (Hiro, 2004) }\end{array}$ & $\begin{array}{l}\text { Data Situs resmi BUMN } \\
\mathbb{C}=\frac{\sum \text { Anggota } K \text { dari luar }}{\sum \text { Total anggota } K}\end{array}$ \\
\hline
\end{tabular}

\section{Keterangan :}

\begin{tabular}{|c|c|}
\hline CAR = Capital Adequacy Ratio & $\mathrm{AC}:$ Audit Comitte \\
\hline CSR $=$ Corporate Social Responbility & EA : Environmental Awareness \\
\hline $\mathrm{RX}=$ Transaksi & Income : Pendapatan \\
\hline
\end{tabular}

\section{Hasil Penelitian dan Pembahasan}

Penelitian ini dilakukan dengan populasi pada perusahaan-perusahaan BUMB di IDX Indonesia. Perusahaan yang dijadikan sebagai sampel pada penelitian ini adalah perusahaaan kontruksi sektoral property dan terdaftar di Komapas100 periode 2013-2015 sesuai dengan kriteria metode purposive sampling yang telah dijelaskan pada bab sebelumnya. Berdasarkan kriteria tersebut terpilih sebanyak 25 perusahaan dari 60 peruahaan kontruksi sebagai berikut :

Guna memberikan gambaran variabelvariabel yang digunakan dalam penelitian ini, yaitu Kualitas Laba (Y), Kesadaran Lingkungan (X1), CSR (X2) dan Komite Audit sebagai moderasi.
Pada Variabel Corporate Social Responsbility memiliki kisaran nilai antara Rp.1.238.000.000-Rp.57.998.000.000 dengan nilai rata-rata Rp.21.285.000.000 dan standar deviasi Rp.13.347.000.000 Hal ini mengindikasikan bahwa perusahaan kontruksi cenderung mengganggap penting Corporate Social Responsbility (CSR). Variabel kesadaran lingkungan memiliki kisaran nilai antara 0.00075 - 0.04 dengan nilai rata-rata 0.018 dan standar deviasi 0.0118 . Hal ini mengindikasikan bahwa perusahaan kontruksi cenderung mengganggap penting kesadaran lingkungan.

Tabel 3 Statistik Deskriptif Peruasahaan Kontruksi (dalam Jutaan)

\begin{tabular}{lccccrr}
\hline & $\begin{array}{c}\text { Jumlah } \\
\text { Sampel } \\
\text { (n) }\end{array}$ & Min & Max & Range & Mean & $\begin{array}{r}\text { Standar } \\
\text { Deviasi }\end{array}$ \\
\hline $\begin{array}{l}\text { Kesadaran } \\
\text { lingkungan (X1) }\end{array}$ & 25 & 0.00075 & 0.04029 & 0.03954 & 0.01831 & 0.01179 \\
CSR (X2) & 25 & 1.238 & 57.998 & 56.760 & 21.285 & 13.347 \\
Komite Audit (M) & 25 & 0.25 & 0.52 & 0.27 & 0.376 & 0.082 \\
\hline
\end{tabular}

Sumber: Data SPSS diolah, 2016 
Pada Variabel komite Audit memiliki kisaran nilai antara $0.25-0.52$ komite dengan nilai rata-rata 0.376 komite dan standar deviasi 0.082 komite Hal ini mengindikasikan bahwa perusahaan kontruksi cenderung setiap perusahaan kontruksi memiliki komite independen 0.25 sampai dengan 0.5 dari jumlah seluruh komite. Pada variabel kualitas laba, penilaian terhadap kualitas laba memiliki kisaran nilai Rp.61.893.000.000 - Rp.2.899.942.000.000 dengan nilai rata-rata Rp.1.064.298.000.000 dan standar deviasi Rp.667.384.000.000. Hal ini mengindikasikan bahwa pencapaian kualitas oleh perusahaan kontruksi laba dianggap sudah baik. Perusahaan kontgruksi memiliki laba bersih terendah Rp.61.893.000.000 dan tertinggi
Rp.2.899.942.000.000 sedangkan rata-rata perusahaan kontruksi mencapai laba bersih adalah sebesar Rp.1.064.298.000.000.

\section{Uji Hipotesis dan Full Model}

Analisis yang dilakukan bertujuan untuk mengetahui hubungan variabel eksogen (Kesadaran Lingkungan dan CSR) dengan variabel endogen (Kualitas Laba). Terdapat hipotesis hubungan yang akan diuji apakah ada pengaruh antara Kesadaran lingkungan $\left(\mathrm{X}_{1}\right)$ dan CSR $\left(\mathrm{X}_{2}\right)$ dengan Kualitas Laba (Y). Untuk mengujinya digunakan program WarpPLS 4.0. Hasil pengolahan dengan program tersebut dapat dilihat pada gambar berikut.

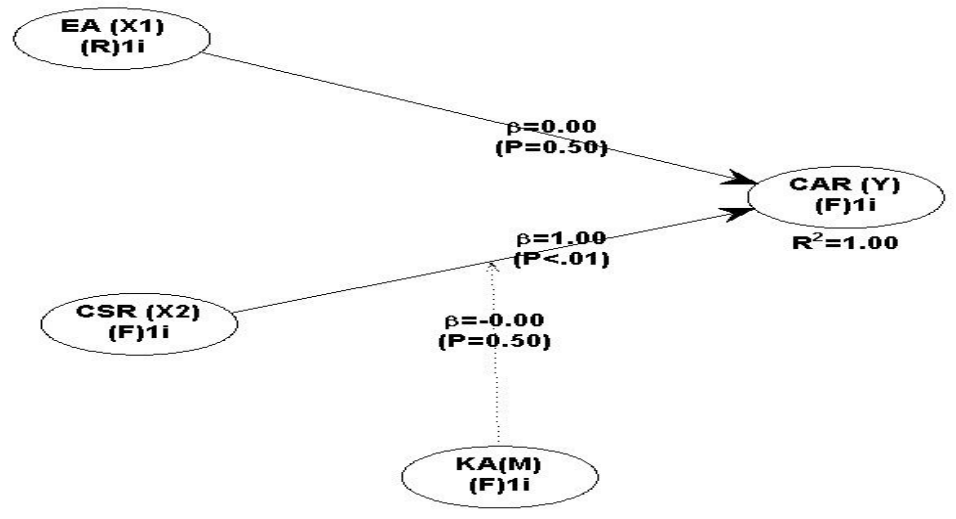

Tabel 4 Model Fit and Quality Indices

\begin{tabular}{|c|c|c|}
\hline \multicolumn{3}{|c|}{ Model Fit and Quality Indices } \\
\hline \multicolumn{3}{|c|}{ Average path coefficient $(\mathrm{APC})=0.333, \mathrm{P}<0.001$} \\
\hline \multicolumn{3}{|c|}{ Average R-squared (ARS)=1.000, $\mathrm{P}<0.001$} \\
\hline \multicolumn{3}{|c|}{ Average adjusted R-squared (AARS) $=1.000, \mathrm{P}<0.001$} \\
\hline \multirow{3}{*}{\multicolumn{3}{|c|}{$\begin{array}{l}\text { Average block VIF }(\mathrm{AVIF})=3.684, \text { acceptable if }<=5 \text {, ideally }<=3.3 \\
\text { Average full collinearity VIF (AFVIF) }=\text { Inf, acceptable if }<=5 \text {, ideally }<=3.3 \\
\text { Tenenhaus } \mathrm{GoF}(\mathrm{GoF})=1.000, \text { small }>=0.1 \text {, medium }>=0.25 \text {, large }>=0.36\end{array}$}} \\
\hline & & \\
\hline & & \\
\hline Jalur & Path Coeficient ( $\beta$ ) & P Value \\
\hline $\mathrm{EA} \rightarrow \mathrm{CAR}$ & 0.000 & 0.500 \\
\hline $\mathrm{CSR} \rightarrow \mathrm{CAR}$ & 1.000 & $<0.001$ \\
\hline $\mathrm{KA} * \mathrm{CSR} \rightarrow \mathrm{CAR}$ & -0.000 & 0.500 \\
\hline
\end{tabular}


Kofisien jalur dan nilai $\mathrm{P}$ pada setiap hubungan langsung eksogen dengan endogen dalam model penelitian. Jalur kesadaran lingkungan terhadap kualitas laba (EA $\rightarrow$ CAR) menunjukan nilai koefisen $0.000(0 \%)$ dan tidak signifikan dengan nilai $\mathrm{P}=0.500$. Sedangkan jalur Corporate Social Responsbility terhadap kualitas laba (CSR $\rightarrow$ CAR) menunjukan nilai koefisen $1.000(100 \%)$ dan signifikan dengan nilai $\mathrm{P}=<$ 0.001. Jalur Komite Audit yang memoderasi hubungan Corporate Social Responsbility terhadap kualitas laba (KA * CSR $\rightarrow$ CAR) menunjukan nilai koefisien -0.000 dan tidak signifikan dengan nilai $\mathrm{P}=0.500$.

Koefisien R-squared $\left(\mathrm{R}^{2}\right)$, Q-squared $\left(Q^{2}\right)$ dan Full collinearity VIFs. Dari tabel diatas dapat dilihat bahwa Nilai Rsquare pada variebel kualitas laba (CAR) sebesar 100\% dan sisanya $0 \%$ dipengaruhi faktor lain. Artinya variabel kualitas laba hanya dipengaruhi oleh CSR sebesar $100 \%$, sedangkan variabel kesadaran lingkungan tidak ada pengaruh nya terhadap kualitas laba.

Nilai Q-squared digunakan untuk mengetahui apakah model mempunyai predictive relevance atau tidak. Nilai $\mathrm{Q}^{2}>0$ menunjukan model mempunyai predictive relevance sedangkan Nilai $\mathrm{Q}^{2}<0$ menunjukan model kurang memiliki predictive relevance. Model penelitian mempunyai predictive relevance karena nilai $\mathrm{Q}^{2}$ diatas 0 .

Nilai Full collinearity VIFs merupakan hasil pengujian kolinearitas penuh yang meliputi multikolenearitas vertical dan lateral. Kriteria untuk Full collinearity VIFs tes adalah nilainya harus lebih rendah dari 3.3 (Kock, 2013). Berdasarkan nilai Full collinearity VIFs yang berada dibawah 3.3 menunjukan didalam model penelitian tidak terdapat mulitikolineritas.

Uji secara individual (partial) diperoleh berdasarkan nilai Sig Kesadaran Lingkungan terhadap Kualitas Laba. Hasil uji individual Kesadaran Lingkungan berkontribusi tidak signifikan terhadap Kualitas Laba diperoleh nilai Sig 0,500. Karena nilai probabilitas 0,05 lebih kecil dengan nilai probabilitas Sig atau 0,05<
0,500, maka Ho diterima dan Ha ditolak artinya koefisien analisis jalur adalah tidak Signifikan. Jadi pengaruh Kesadaran Lingkungan tidak signifikan terhadap Kualitas Laba.

Uji secara individual (partial) diperoleh berdasarkan nilai Sig CSR terhadap Kualitas Laba. Hipotesis penelitian yang akan di uji dirumuskan berbentuk hipotesisi statistik sebagai berikut. Hasil uji individual CSR berkontribusi secara signifikan terhadap Kualitas Laba diperoleh nilai Sig 0,001. Karena nilai probabilitas 0,05 lebih besar dengan nilai probabilitas Sig atau 0,05 > 0,001, maka Ho ditolak dan Ha diterima artinya koefisien analisis jalur adalah Signifikan. Jadi CSR berkontribusi secara signifikan terhadap Kualitas Laba. Uji model moderasi diperoleh berdasarkan nilai Sig CSR terhadap Kualitas Laba yang dimoderasi oleh komite audit. Hipotesis penelitian yang akan di uji dirumuskan berbentuk hipotesisi statistik sebagai berikut.

Hasil uji imodel moderasi CSR berkontribusi tidak signifikan terhadap Kualitas Laba diperoleh nilai Sig 0,500. Karena nilai probabilitas 0,05 lebih kecil dengan nilai probabilitas Sig atau 0,05<0,500, maka Ho diterima dan $\mathrm{Ha}$ ditolak artinya koefisien analisis jalur adalah tidak Signifikan. Jadi pengaruh komite audit memoderasi negatife (memperlemah) pengaruh CSR terhadap Kualitas Laba. Berdasarkan hasil pengujian hipotesis dan model moderasi maka dapat disimpulkan sebagai berikut.(tabel.5)

Hasil uji terhadap koefisien parameter antara Kesadaran Lingkungan terhadap Kualitas Laba menunjukkan tidak ada pengaruh dengan nilai P Value sebesar 0.500 dan signifikan pada $\alpha=5 \%$. Nilai T-Statistic tersebut berada jauh diatas nilai kritis (0.05). Hal yang berbedaga terjadi pada hubungan variabel CSR dengan CAR, menunjukan Nilai Probabilitas (PValue) tersebut berada jauh dibawah nilai kritis (0.05). Sehingga hanya CSR yang berpengaruh postif dan signifikan terhadap Kualitas Laba. 
Tabel 5. Ringkasan Hasil Pengujian Hipotesis dan Model Moderasi

\begin{tabular}{|c|c|c|c|c|}
\hline Hubungan Antar Variabel & $\begin{array}{c}\text { Nilai } \\
\text { Koefisoen } \\
(\beta) \\
\end{array}$ & $\begin{array}{l}\text { Nilai } P \\
(\leq 0.05)\end{array}$ & $\mathbf{H}_{\mathbf{a}}$ & Kesimpulan \\
\hline $\begin{array}{l}\text { Hipotesis 1 : } \\
\text { Kesadaran Lingkungan terhadap } \\
\text { Kualitas Laba } \\
(\text { EA } \rightarrow \text { CAR })\end{array}$ & 0.000 & 0.500 & Ditolak & $\begin{array}{l}\text { Tidak ada } \\
\text { pengaruh dan } \\
\text { tidak signifikan }\end{array}$ \\
\hline $\begin{array}{c}\text { Hipotesis } 2: \\
\text { CSR terhadap Kualitas Laba } \\
(\mathrm{CSR} \rightarrow \mathrm{CAR})\end{array}$ & 1.000 & 0.001 & Diterima & $\begin{array}{l}\text { Berpengaruh } \\
\text { Positif dan } \\
\text { Signifikan }\end{array}$ \\
\hline $\begin{array}{c}\text { Hipotesis } 3 \text { : } \\
\text { CSR terhadap Kualitas Laba yang } \\
\text { dimoderasi oleh komite audit } \\
(\mathrm{KA} * \mathrm{CSR} \rightarrow \text { CAR })\end{array}$ & -0.000 & 0.500 & Ditolak & $\begin{array}{c}\text { Tidak ada } \\
\text { pengaruh dan } \\
\text { memperlemah } \\
\text { pengaruh CSR } \\
\text { terhadap CAR }\end{array}$ \\
\hline
\end{tabular}

Sumber: Data Diolah, 2016

\section{Kesadaran Lingkungan Terhadap Kualitas} Laba.

Hasil uji terhadap koefisien parameter antara kesadaran lingkungan terhadap kualitas laba BUMN di Indonesia menunjukkan terdapat pengaruh langsung sebesar $0 \%$. Koefisien yang dihasilkan adalah 0.000 dengan nilai Pvalue 0.5, artinya tidak ada pengaruh yang signifikan antara kesadaran lingkungan berpengaruh terhadap kualitas laba BUMN. Karena ada kecenderungan rata-rata industri kontruksi menyajikan kesadaran lingkungan tidak begitu terperinci baik dari aspek akuntansi dan faktor keuangan, litigasi lingkungan, pencegahan polusi lingkungan, dan aspek lainnya, hanya sekadar menunjukkan bahwa perusahaan telah melakukan kegiatan sosial yang berkaitan dengan lingkungan.

Kesadaran lingkungan merupakan jenis pengungkapan sukarela (voluntary disclosure) informasi kesadaran lingkungan dari sudut pandang fungsi eksternal akuntansi lingkungan. Rata-rata industri kontruksi menyajikan pengungkapan akuntansi lingkungan tidak begitu terperinci, baik dari aspek akuntansi dan faktor keuangan, litigasi lingkungan, pencegahan polusi lingkungan, maupun aspek lainnya. Pengungkapan tersebut masih bersifat umum dan jarang yang ditampilkan dalam bentuk moneter atau kuantitatif. Dari hal tersebut menunjukkan bahwa rata-rata industri kontruksi dalam mengungkapkan kesadaran lingkungan hanya sekadar menunjukkan bahwa perusahaan telah melakukan kegiatan sosial yang berkaitan dengan lingkungan.

\section{Corporate social responsibility Terhadap Kualitas Laba}

Hasil uji terhadap koefisien parameter antara Corporate social responsibility terhadap kualitas laba BUMN di Indonesia menunjukkan terdapat pengaruh langsung sebesar $100 \%$. Nilai Pvalue tersebut berada jauh dibawah nilai alpha pembanding. Koefisien yang dihasilkan adalah 1.000 dengan nilai Pvalue 0.001, artinya ada pengaruh yang signifikan antara Corporate social responsibility berpengaruh terhadap kualitas laba BUMN. Semakin tinggi indeks CSR maka semakin tinggi pula kualitas laba perusahaan kontruksi dan sebaliknya

Corporate social responsibility sebagai komitmen dunia bisnis dalam berkontribusi dalam pembangunan ekonomi berkelanjutan. Kerja sama dengan para karyawan serta perwakilan mereka, keluarga mereka, komunitas setempat 
maupun masyarakat umum untuk meningkatkan kualitas kehidupan dengan cara yang bermanfaat baik bagi bisnis sendiri maupun untuk pembangunan. Sekarang dunia bisnis dituntut untuk mampu menyeimbangkan pencapaian kinerja ekonomi (profit), kinerja sosial (people), dan kinerja lingkungan (planet) atau disebut triple bottom-line performance. Orientasi praktik bisnis yang selama ini pada maksimalisasi laba perlu dikaji ulang. Orientasi mengejar laba semaksimal mungkin, secara jangka pendek akan menunjukkan keberhasilan, namun untuk jangka panjang hal tersebut bisa menimbulkan masalah bagi perusahaan karena adanya resistensi dari masyarakat dan stakeholder lainnya.

\section{Komite Audit Sebagai Pemoderasi Hubungan CSR Dengan Kualitas Laba}

Hasil uji terhadap koefisien parameter antara corporate social responsibility terhadap kualitas laba BUMN yang dimoderasi oleh komite audit menunjukkan tidak ada pengaruh komite audit independen dan memperlemah pengaruh Corporate social responsibility terhadap Kualitas Laba. Pengaruh komite audit belum berperan positif dalam meningkatkan kualitas laba. Namun demikian peran komite audit di masa depan akan semakin diperlukan untuk melaksanakan Good Corporate Government dan CSR. CSR sendiri merupakan salah satu peran dalam meningkatkan tingkat kesejahteraan lingkungan. Oleh karena itu komite audit perlu mendorong dan menjawab permasalahan untuk melaksanakan kegaiatan CSR sesuai dengan peraturan perundangan yang berlaku.

Hasil penelitian menunjukan sebaliknya bahwa komite audit tidak memiliki peran dalam mendorong pelaksanaan CSR. Bagi komite audit, pelaksanaan CSR hanya didasarkan keuntungan labayangpositif.Jikamenguntungkanperusahaan, maka CSR dapat dilaksanakan dengan baik, begitupun sabaliknya jika kualita laba tidak positif maka CSR pun belum mampu menyeimbangankan terhadap kebutuhan lingkungan. Peran dan tugas komite audit adalah bertanggung jawab, antara lain atas persiapan, penyajian, dan integritas laporan keuangan; prinsip-prinsip pelaporan akuntansi dan keuangan; pengendalian internal dan prosedur organisasi yang sesuai dengan standar akuntansi keuangan serta hukum dan peraturan yang berlaku. Komite audit hanya bertanggung jawab untuk melakukan audit secara independen atas laporan keuangan konsolidasi berdasarkan standar auditing yang berlaku umum dan menyatakan pendapat atas laporan keuangan konsolidasi berdasarkan audit mereka. Jadi peran audit tidak berhubungan dengan kegiatan CSR dan kondisi kualitas laba perusahaan, melainkan hanya sebagai pengawasan atas pelaksanaan CSR saja.

\section{Simpulan, Keterbatasan, dan Implikasi Hasil Penelitian}

Berdasarkan pada hasil penelitian serta pengujian hipotesis dapat ditarik kesimpulan penelitian sebagai berikut (1) Tidak ada pengaruh yang signifikan antara kesadaran lingkungan berpengaruh terhadap kualitas laba BUMN. Karena ada kecenderungan rata-rata industri kontruksi menyajikan kesadaran lingkungan tidak begitu terperinci baik dari aspek akuntansi dan faktor keuangan, litigasi lingkungan, pencegahan polusi lingkungan, dan aspek lainnya, hanya sekadar menunjukkan bahwa perusahaan telah melakukan kegiatan sosial yang berkaitan dengan lingkungan. (2) Ada pengaruh yang signifikan antara Corporate social responsibility berpengaruh terhadap kualitas laba BUMN. Semakin tinggi indeks CSR maka semakin tinggi pula kualitas laba perusahaan kontruksi dan sebaliknya. (3) Tidak ada Pengaruh Komite Audit Independen dan memperlemah pengaruh Corporate social responsibility terhadap Kualitas Laba. Pengaruh komite audit belum berperan positif dalam meningkatkan kualitas laba, karena bersifat independen. Namun demikian peran komite audit di masa depan akan semakin diperlukan untuk melaksanakan Good Corporate Government dan CSR.

Penelitian ini memiliki keterbatasan, diantaranya adalah : bahwa penggunaan variabel moderating memungkinkan menggunakan variabel intervening. Selain itu, penelitian ini 
hanya menggunakan data perusahaan selama tiga tahun. Saran yang dapat diberikan untuk penelitian selanjutnya adalah (1) Dari hasil penelitian yang telah dikemukakan di atas menunjukkan bahwa rata-rata BUMN kontruksi menyajikan akuntansi lingkungan secara sukarela (voluntary), bahkan ada beberapa BUMN kontruksi yang tidak menyajikan sama sekali. Hal ini diperkuat dengan hasil kesadaran lingkungan secara keseluruhan tidak ada pengaruh yang signifikan terhadap kualitas laba. Padahal kesadaran lingkungan sangat penting sebagai salah satu bentuk legitimasi antara perusahaan dan masyarakat. (2) Penambahan variabel lain, misalnya dengan menambahkan proxy variabel komite audit lain yang mungkin dapat mempengaruhi kualitas laba. (3) Penambahan periode penelitian agar dapat memberikan hasil penelitian dalam scope yang lebih luas. Penggunaan variabel intervening dalam model penelitian.

\section{Daftar Rujukan}

Belkaoui, Bronson. N. Scott, Joseph V. Carcello, Carl W. Hollingsworth, Terry L. Neal. 2009. "Are fully independent audit committees really necessary?". Journal of Accounting and Public Policy. Vol.28. No.4. Hal. 265280

Carrol, Chih, Lin Hsiang. Chuang Hua Shen, Feng Ching Kang. 2008. "Corporate social responsibility, Investor Protection, and Earnings Management: Some International Evidence". Journal of Business Ethics. 79(1-2) : 179-198

Choi, Bo Bae. Doowon Lee. Youngkyu Park. 2013. "Corporate social responsibility, Corporate Governance and Earnings Management : Evidence from Korea". Corporate Governance : An International Review. 21(5) : 447-467

Ghozali, Imam dan A. Chariri, 2007, Teori Akuntansi, Badan Penerbit Universitas Diponegoro, Semarang.

Ghozali, Imam. 2006. Aplikasi Analisis Multivariate dengan Program SPSS. Badan Penerbit Undip
Ikhsan, Arfan. 2008. Akuntansi Lingkungan \& Pengungkapannya. Yogyakarta: Graha Ilmu. Isyanto, Silviana, Ratnaningsih, Dewi, Pengaruh Corporate social responsibility Terhdapa Kualitas Laba (StudiEmpiris Pada Perusahaan Manufaktur Yang Terdaftar Di BEITahun 2009 - 2012) Jurnal Ekonomi Akuntansi,

Komite Nasional Kebijakan Governance. 2006.

"Pedoman Good Corporate Governance Indonesia"

Mayangsari, Sekar. 2001. "Manajemen Laba dan CSR Manajemen". Media Riset Akuntansi, Auditing dan Informasi. 1 (2) : 49-70

Nuswandari, Cahaya. 2009. Pengaruh Corporate Governance Perception Index terhadap Kualitas Laba Perusahaan pada Perusahaan yang Terdaftar di Bursa Efek Jakarta. Jurnal Bisnis dan Ekonomi Vol. 16 No. 2. Tersedia di http://www.unisbank.ac.id/ojs/index.php/ fe3/article/view/316. Diakses pada 21 Maret 2016.

Paulus. Christian, 2012, Analisis FaktorFaktor Yang Mempengaruhi Kualitas Laba, Fakultas Ekonomi Universitas, Diponegoro, Semarang, Skripsi.

Pratiwi, Wahyu Mega. 2013. Akuntansi Lingkungan Sebagai Strategi Pengelolaan dan Pengungkapan Tanggung Jawab Lingkungan pada Perusahaan Manufaktur. Jurnal Akuntansi Unesa Vol. 2 No. 1.

Prior, Diego. Jordi Surroca. Josep A. Tribo. 2007. Earnings Management and Corporate social responsibility. Working Paper. Universidad Carlos III de Madrid

Rahman, R, 2009, Corporate social responsibility Antara Teori dan Kenyataan, Yogyakarta : Media Pressindo.

Scott, R. William. 2009. Financial Accounting Theory. Fifth Edition. Canada : Prentice Hall

Surifah, 2010, Kualitas Laba dan Pengukurannya, Jurnal Ekonomi, Manajemen \& Akuntansi, Vol. 8 No. 2 Mei - Agustus 2010

Susanto, Priyatna Bagus, Subekti. Imam, Pengaruh Corporate Social Responibility dan Good Governance terhadapat Bilai Perusahaan (Pada Perusahaan yang Terdaftar 
di Bursa Efek Indonesia), Jurnal Ilmiah Mahasiswa Fakultas Ekonomi dan Bisnis, http://jimfeb.ub.ac.id/index.php/jimfeb/ article/view/410.

Umami, Elok Harmatil. 2010. Faktor-faktor yang Mempengaruhi Pengungkapan Akuntansi Lingkungan dalam Laporan Tahunan Perusahaan. Jurnal Ilmiah Mahasiswa FEB Vol. 2 No. 1

Widayanti, A Chusnulia, Dkk, 2014, Faktorfaktor yang mempengaruhi Kualitas Laba pada Perusahaan High Profile yang Terdaftar di BEI, Jurnal Dinamika Ekonomi \& Bisnis,Vol. 11 No. 1 